\title{
Specifics in strategic management of non-profit organizations in the globalization process
}

\author{
Eva Kicová ${ }^{1, *}$, and Olga Poniščiaková ${ }^{1}$ \\ ${ }^{1}$ University of Zilina, Faculty of Operation and Economics of Transport and Communications, \\ Department of Economics, Univerzitna 1, 01026 Zilina, Slovakia
}

\begin{abstract}
.
Research background: If globalization presents really a new and not reversible process that creates a more homogenous world, strategies of enterprises should appropriate to this phenomenon, too. European legislation has significantly contributed to the creation of the mutual market and increasing freedom of movement of services within the European Union. Its basic principle can be applied to the harmonization of basic requirements for services and the subsequent normalization - the creation of common European standards. This also applies to the area of non-profit organizations. These organizations are an important part of the public sector, which in the form of various activities, in particular the providing of various services, performs tasks related to addressing manifestations of market imbalances. In contrast to the "traditional" business sector (profit sector), the task of the non-profit sector is not to generate profit but to provide consumer tasks.

Purpose of the article: The objective of the article is to clarify and present the specifics of functioning and management of non-profit organizations in the conditions of the Slovak Republic.

Methods: During the elaboration of the paper, the methods of compilation of analysis, synthesis and description were used on the basis of the search of the relevant literature. Part of the paper is a survey, which we conducted through a questionnaire on a selected sample of non-profit organizations in the Slovak Republic.

Findings \& Value added: The results of the survey we have transported into general practice recommendations for non-profit organizations to improve their operating in the conditions of Slovakia while accepting the process of globalization.
\end{abstract}

Keywords: non-profit organizations; strategic management; specifics; process of globalization

JEL Classification: $M 30 ; M 31 ; M 39$

\footnotetext{
${ }^{*}$ Corresponding author: eva.kicova@fpedas.uniza.sk
} 


\section{Introduction}

The world has been changing due to globalization. Currently, there are more than 69 thousand non-profit organizations in Slovakia and their numbers have been growing. The non-government sector in Slovakia is often in the interaction with many changes. Nonprofit organizations often do not know how will be financed in the long run perspective, as this often depends on current grant projects, which are not long-term oriented. Thus, because of globalization, non-profit organizations must, based on these facts, place greater emphasis on more effective strategic management, which is currently largely based only on the theoretical knowledge of the strategic management of profit-oriented organizations. Non-government sector as well as profit sector need to link their mission, vision, strategy and goals with projects, which they participate in, and need to measure their efficiency. However, there are many non-profit organizations in Slovakia, which do not pay any attention to strategic management of the organization or very little attention.

\subsection{Characteristics of non-profit sector}

The non-profit world and business world were once referred to as two opposites based on fundamentally different values. Entrepreneurs often understood the non-profit sector as poor, nonconceptual, or amateurish. In contrast, charismatic leaders of non-profit organizations spoke of business as something of a false, filthy, and desecrating vision and mission of the organization. Recently, however, there have been opinions that these two seemingly opposing sectors can learn and enrich each other, and even non-profit organizations play a dominant role in this regard.

In the non-profit sector we can meet with a wide range of commonly used terms as third sector, civic sector, non-government sector, public sector, private non-government sector, non-profit organizations, non-government organizations - government non-profit organizations, voluntary organizations, civil society organizations or community organizations $[1,2]$. Although there are an obvious terminological diversity, we most often meet with the term non-profit organizations or non-government non-profit organizations [3].

The third sector is one of the basic pillars of the civil society and an important element of social stability. It is a tool of change in the life of a human being a thereby a whole society $[4,5,6]$.

Rebet'ák and Bartošová presents an opinion that the main difference between the profit and the non-profit sector is the reason for establishing. Enterprises are established for making a profit, while for non-profit organizations this reason does not exist (is not paramount). This fundamental difference also implies all other differences [7].

Abaida and Lin states that the primary difference between a non-profit organization and a company is that the profit is not possible to distribute among the owners of the non-profit organization [3].

Mazanec and Bartošová, the USA is a country that is an example of the influence of the non-profit sector on the creation and shaping of the country's social development. Most of important social movements, which have emerged in the USA in recent decades, have emerged from the activities of the non-profit sector, whether it is a civil rights movement, a consumer movement, or a movement for the protection of monuments, etc. [8]. We also can generally say that it is common in Europe that countries appoint specific purposes in their legislation, which, in their view, is considered to serve the public welfare. Any legal activity that promotes or supports multiple purposes or one purpose specified by law is considered a public benefit activity. However, in several countries, in addition to these 
well-defined terms, also a general category includes other activities serving the public welfare [7, 9 - 11].

Top managers of non-profit organizations pay much less attention to strategic management in comparison to managers in the business sector. This fact is influenced not only by differences between the business sector and non-profit sector, but also by large differences between the non-profit organizations themselves. Wortman, who devotes to the research of non-profit organizations, argues that non-profit organizations were still in the early stages of applying the principles of strategic planning [7].

In the case of the problem of measuring performance of management processes in nonprofit organizations, we can say that the availability of literary sources focused on this issue is significantly absent. The only exceptions are foreign publications, which combine a "classic" understanding of the performance of business processes with processes in nonprofit organizations $[3,7,12,13,14]$.

According to Nadanyiova and Durana, the traditional methods of measuring performance of processes have basic shortcomings in it that they are only able to provide a retrospective view of the competitive position of the analysed organization, whose activities have only been recorded in a certain period in the past [14]. Analyses of this type are incomplete and outdated. They are able to provide only a small number of usable options for revealing the true variability and dynamics of factors that speak about the profitability of an organization. As a result, the traditional methods of measuring process efficiency need to be complemented by a set of non-financial, more dynamic indicators that are tailored to the specific competitive conditions of the organization.

Non-profit organizations are established with a certain mission (sometimes it is quite clear, clearly worded, sometimes too much abstract, and only guessed). The founding members of the organization perceive it as key and all activities performed are aimed at its fulfilment. However, the reality is often that over time, the mission gets behind and other motives become more important. It may happen that the organization perceives its strengths and builds on successful projects, but it is stuck and loops in itself if it does not perceive new opportunities and challenges. Alternatively, on the other hand, it perceives a number of opportunities and wants to respond to them, but does not address whether it is fulfilling its mission at the same time, whether it has the capacity to complete a new project to a successful end. In addition, clinging to a mission that is not relevant because it has long been fulfilled is a brake on development. Determining the organization's strategy is, after defining its mission, one of the basic preconditions for moving forward. It is needed to be aware of where the organization wants to go, what conditions it has to respect on this path and what obstacles it has to overcome. $[15,16]$.

\section{Methodology}

Strategic management and strategy elaboration is a new process for the most of non-profit organizations. It is necessary to master the principles of strategic thinking and be aware of specifics of strategic processes to manage it.

In most of non-profit organizations in the Slovak Republic, the founder of the organizations is the creator of the organization's vision. An effective vision should inspire, activate, motivate and provide emotional guidance. It is important to have not only a precisely formulated vision, but also a precisely formulated mission of the organization. The mission is not a static and unchanging quantity. Regularly, the organization's management should think about whether the mission does not need to change, e.g. because the demographic structure of customers has changed, or because the organization's activities do not bring the desired results, or because activities far exceed the organization's 
resources and capabilities, or simply because the organization's goals have already been achieved and met. $[9,12,15]$.

Based on the study of strategic procedures of various authors, it can be stated that at the theoretical level there are a number of schematic procedures of strategic management of non-profit organizations, which however do not differ from the strategic management of profit-oriented organizations and do not take into account their specifics.

The concept of customer is quite common in the business world and companies in most cases can accurately identify their customers. In the case of non-profit organizations, however, the term customer has not been defined for a long time, and many organizations have even avoided this term. Instead, the term customer, the term "beneficiaries", i.e. people who receive something from the organization is preferred. Unfortunately, in many non-profit organizations, customers are still seen as recipients, e.g. like a poor people who have some problems, who are not very smart, intelligent or educated. It is important to use the word customer in order to change fundamentally the way they look at them $[7,8,15]$. Each non-profit organizations has more than one customer in case that the organization defines customers as people, who can chose between accepting or reject the services. The customers of the non-profit organization include primary customers, i.e. those for whom the organization's products and services are intended, donors, volunteers, and community members.

The non-profit organizations must chose a customer, for whom the organization's mission has a sense. As well as, the organization should be able to cover the needs of one or more groups of customers with the capabilities and disposable resources. The vision of the non-profit organization and its mission should reflect its core values. Only a non-profit organization whose values are clear can work according to them and build its policy on them. The non-profit organization should articulate its values clearly, incorporate them into its way of life, and build its strategies based on them. [10, 16, 17, 18].

To analysis the level of strategic management in non-profit sector in the Slovak Republic, we did a questionnaire survey. Non-profit organizations were questioned through the questionnaire during the March to May 2020. The questionnaire consisted of 16 questions. We contacted 175 randomly selected non-profit organizations from the FinStat.sk database. $68 \%$ of questionnaires came from non-profit organizations located in Zilina Region. According to answers of managers of non-profit organizations, 44\% (11) of them have been working for given non-profit organizations more than 3 years and less than 10 years, $6 \%(9)$ more than 10 years. From the point of view of the legal form of the nonprofit organizations, mostly associations $(68 \%)$ and foundations $(24 \%)$ represented the inquired sample. The rest of asked non-profit organization represented public benefit organizations. Based on the results, $72 \%$ of organizations have been operating in Slovakia more than 25 years, $16 \%$ no more than 5 years. $12 \%$ of non-profit organizations have been operating there from 10 to 15 years.

The non-profit organizations under analysis were financed by self-financing mostly $(56 \%)$. The finance from private sector was the main source of financing for $24 \%$ organizations, the rest of the organizations were financed from the state.

We consider the issue of a defined mission, vision and objectives to be important from the point of view of strategic management. This was supported also by the findings of the questionnaire survey $-100 \%$ of the asked non-profit organizations consider the issue of defined mission, vision and objectives as very important. It was also confirmed that nonprofit organizations are created with a certain mission and without it, they would not make sense.

In the survey, we also focused on finding out the use of specific strategies. The research question had more options; to state one's opinion was also possible. According the results, this option was chosen by $8 \%$ of the asked non-profit organizations. They stated that they 
used a fundraising strategy and a CSR strategy in addition to the listed options. These strategies, according to results, were followed by a quality strategy (20\%), a financial strategy $44 \%$ and a human resources management strategy $36 \%$. However, none of the asked non-profit organizations stated that it used a production strategy that is one of the most used in the profit sector. The findings are presented in the following Figure.

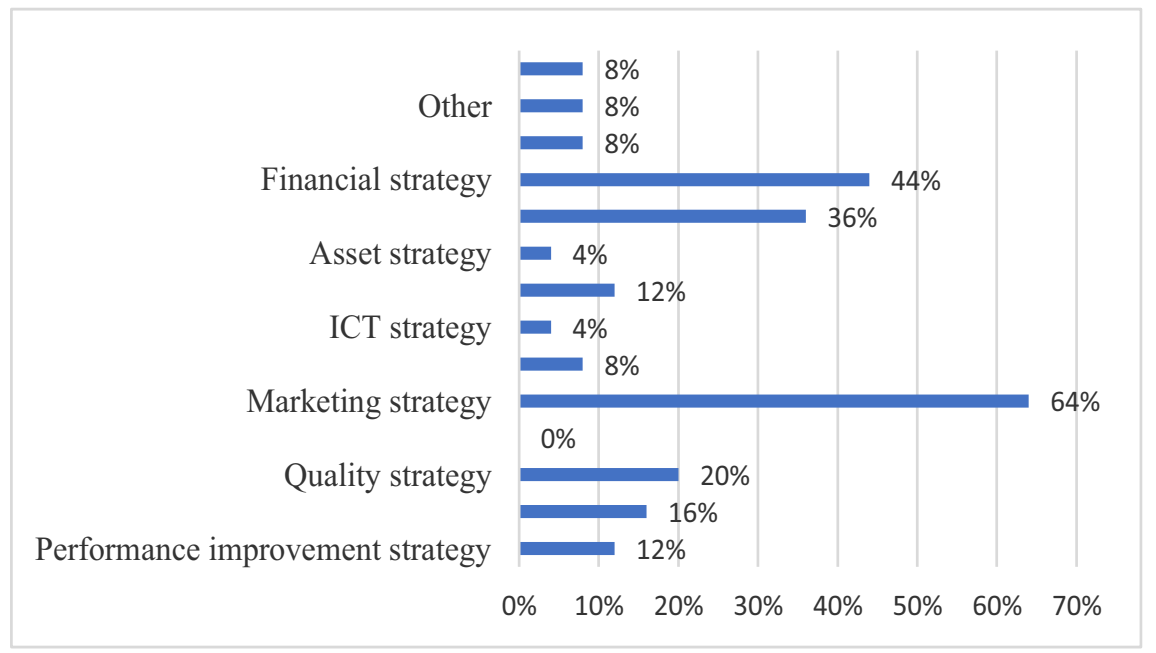

Fig. 1. The use of strategies in non-profit organizations. Source: own design.

According to specific tools of strategic management, the most preferable is the SWOT analysis $(72.7 \%)$ followed by the forecasting (33.3\%), basic marketing concepts $(22.2 \%)$ and the management by objectives $(16.7 \%)$. None from the asked non-profit organizations has been using the SPACE analysis, the PESTLE analysis, the MOST analysis or BCG matrix. Here we can see another specificity of non-profit organizations, because these methods are often used in the profit sector and play an important role in the strategic management of the company. The question also provided to mention own opinion of the respondents. According to this option, only one non-profit organization uses a retrospective analysis focusing on prophylaxis and invention. The summary of the findings are presented in Figure 2. 


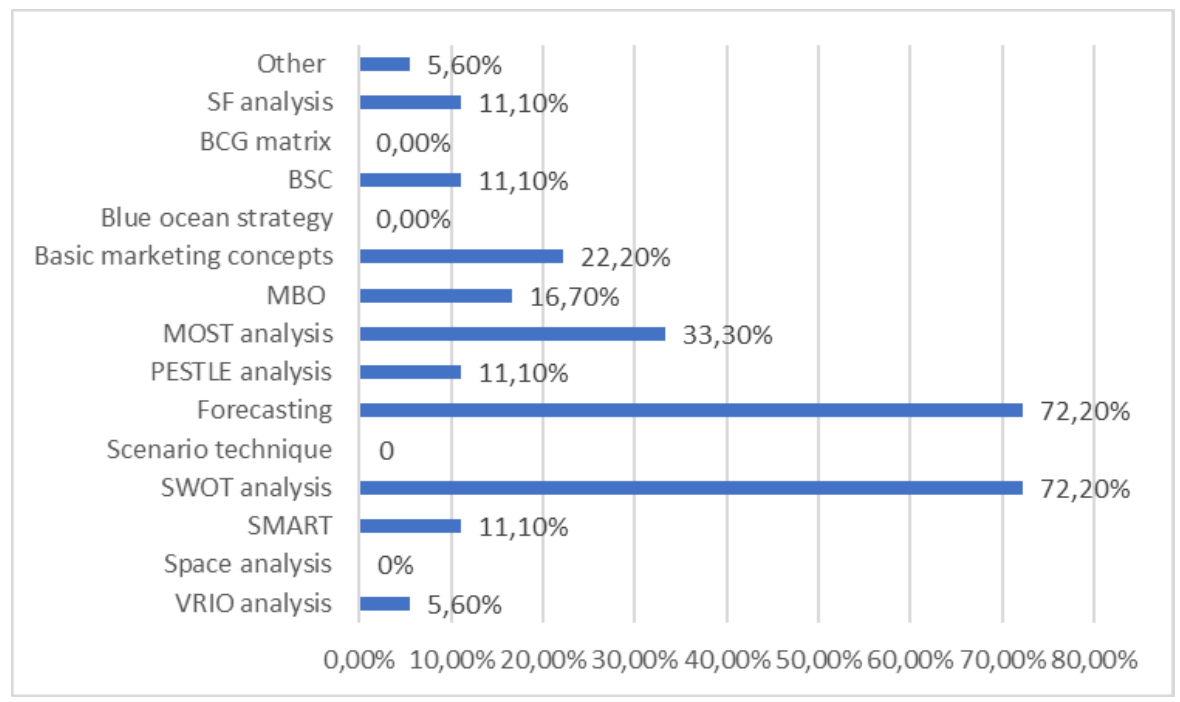

Fig. 2. The use of tools of strategic management. Source: own design.

\section{Results}

Not only in "classic" companies, but also in the case of non-profit organizations, the management of the organization and the associated measurement of process performance is an important tool. In connection with non-profit organizations, we can talk about many differences, but with the right choice of tools and methods for measuring process performance, it is possible also in the case of non-profit organizations to get a picture of the current state of the organization and to plan specific activities to improve the current state.

As a basis for strategic management implanted in non-profit organizations, we created a general model of a strategic map. Because many publications have not been addressed this issue so far, a strategic map was prepared based on the own view of the given issue, while respecting the findings of the questionnaire survey. As can be seen, our strategic map does not express direct links between the individual strategic objectives. These we leave up to each non-profit organization. The suggested strategic map can be considered a background for strategic managers of non-profit organizations. The map is able to respect specific features of non-profit sector and can serve as a basis for a creation of strategic management in each non-profit organizations. 


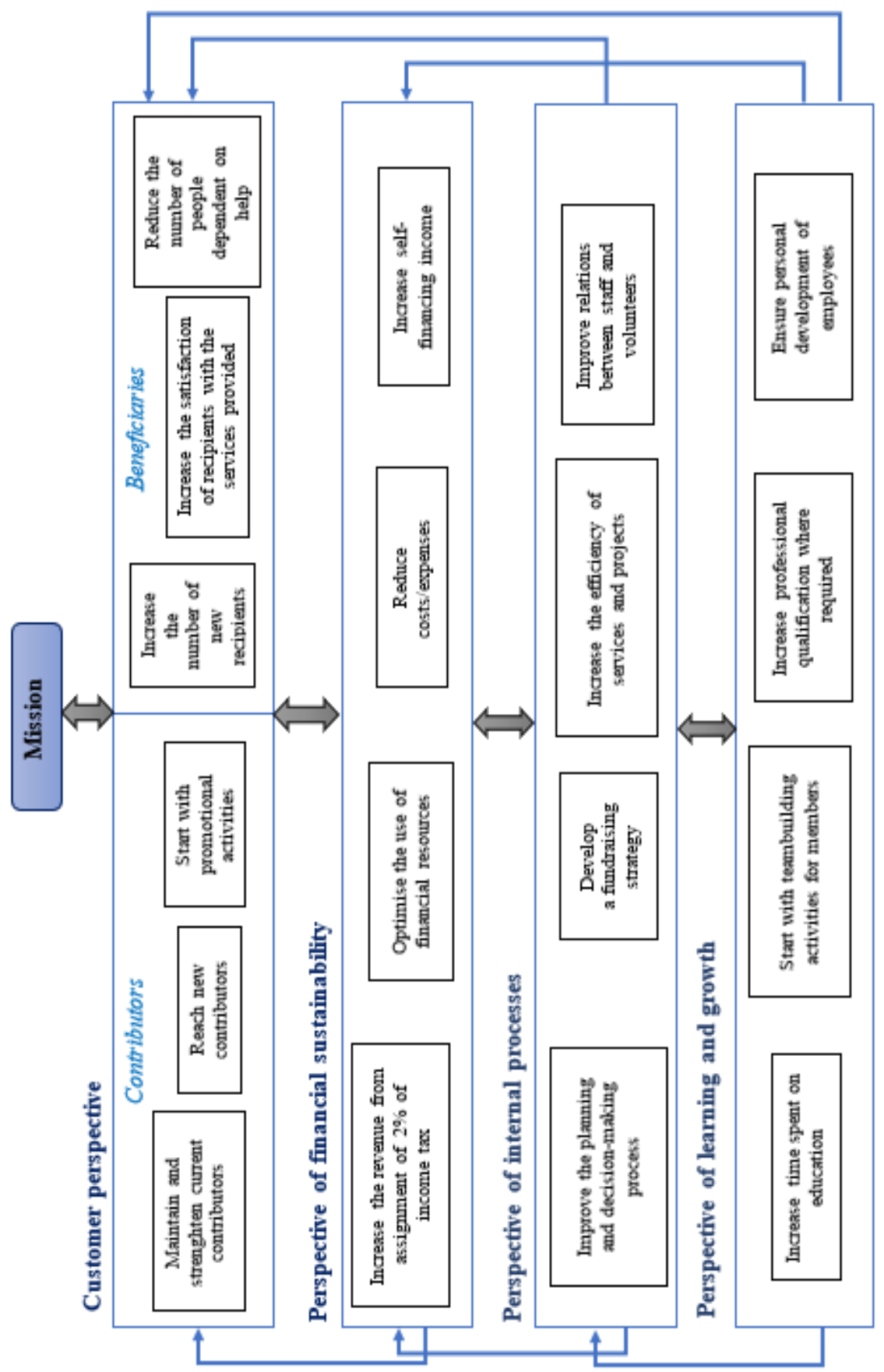

Fig. 3. Model of a strategic map for non-profit organization in Slovak Republic. own design. 


\section{Conclusion}

Globalization brings both opportunities and challenges. At present, the non-governmental sector in Slovakia is often in interaction with many changes as well as with the difficult predictability of a continuous supply of financial resources. Non-profit organizations often do not know how will be financed in the long run perspective, as this often depends on current grant projects that are not long-term oriented. Thus, because of globalization, nonprofit organizations must, based on these facts, place greater emphasis on more effective strategic management, which is currently largely based only on the theoretical knowledge of the strategic management of profit-oriented organizations. The non-government sector as well as profit sector need to link their mission, vision, strategy and goals with projects, which they participate in, and need to measure their efficiency. Precisely for this reason, we focused on the specifics of non-profit organizations as well as the specifics of strategic management in non-profit organizations. Based on the survey, we proposed a strategic map, which can be considered as a basis for strategic management of any non-profit organization as such.

Grant No. 1/0544/19 Formation of the methodological platform to measure and assess the effectiveness and financial status of non-profit organizations in the Slovak Republic

\section{References}

1. Behun, M., Gavurova, B., Tkacova, A., Kotaskova, A. (2018). The Impact of the Manufacturing Industry in the Economic Cycle of European Union Countries. Journal of Competitiveness, 10(1), 23-39.

2. Lyakina, M., Marianne Sh., Podhorska, I. (2019). Networked and Integrated Urban Technologies in Internet of Things-enabled Smart Sustainable Cities. Geopolitics, History, and International Relations, 11(2), 62-68.

3. Abadia, M. G., Lin, J. (2018). Nonprofit cost analysis Toolkit: Six steps to finding the true costs of programs. The Bridgespan Group.

4. Cabral S., Mahoney, J. T., McGahab, A. M. (2019). Value creation and value appropriation in public and nonprofit organizations. Stragegic management Jurnal, 40(4), 465-475.

5. Lai, M. J., Tang, L. Y. (2019). How non-profit organization contribute to change: developing new 2.0 Taiwan dementia plan in response to the WHO global action plan. International psychogeriatrics, 31(1), 149-149.

6. Valjašková, V. Klieštiková, J. (2019). The main aspects of brand portfolio management. In M. L. Simic \& B. Crnkovic (Eds.), Proceedings of the 8th International Scientific Symposium Economy of Eastern Croatia - Vision and Growth (pp. 1253-1260). Osijek, Croatia: Medunarodni Znanstveni Simpozij Gospodarstvo Istocne Hrvatske-Jucer Danas Sutra.

7. Rebetak, F., Bartosova, V. (2019). Non-profit organizations in the conditions of Slovakia. SHS Web of Conferences, 74, 05020.

8. Mazanec, J., Bartošová, V. (2019). Financial vulnerability of non-profit organizations in the Slovak Republic. In K. S. Soliman (Ed.), Education excellence and innovation management through Vision 2020: Proceedings of the 33rd International business information management association conference (pp. 1051-1066). Granada, Spain: IBIMA. 
9. Gajanová, L. (2015). The proposal of competitive intelligence model for enterprises in the Slovak republic as a prerequisite for sustainable development in a global environment. In T. Kliestik (Ed.), Proceedings of the Globalization and its socioeconomic consequences: 15th international scientific conference, Part I. (pp. 135-143). Zilina: University of Zilina.

10. Michalková, L., Klieštik, T. (2017). Optimizing the selection of investment projects based on adjusted net present value. In G. Lee (Ed.), Proceedings of the 5th International conference on applied social science, Part I (298-304). Bellflower: Information engineering research institute.

11. Mularz, C. M. (2014). Analytics for Nonprofits. Encyclopaedia of Business Analytics and Optimization, 115-123.

12. Dobrovič, J., Kmeco, L., Gallo, P., Gallo jr., P. (2019). Implications of the Model EFQM as a Strategic Management Tool in Practice: A Case of Slovak Tourism Sector. Journal of Tourism and Services, 10(18), 47-62.

13. Klieštiková, J. Moravčíková, D. (2017). The power of giving back: Case study of Slovak Republic. In H. Zhang (Ed.), Proceedings of the 4th International conference on Economic, Business Management and Education Inovation (EBMEI 2017) (pp. 1520). Casablanca, Morocco: Lecture Notes in Management Science.

14. Nadanyiova, M., Durana, P. (2019). Corporate social responsibility as a brand valueenhancing tool. In M. L. Simic, B. Crnkovic (Eds.), Proceedings of the 8th International Scientific Symposium Economy of Eastern Croatia - Vision and Growth (pp. 1225-1237). Osijek, Croatia: Medunarodni Znanstveni Simpozij Gospodarstvo Istocne Hrvatske-Jucer Danas Sutra.

15. Miller, H. (2003, March 21). Hidden in Plain Sight: Understanding Nonprofit Capital Structure. The nonprofit Quarterly. http://www.nonprofitfinancefund.org/report/hidden-plain-sight-understandingnonprofit-capital-structure

16. Turcotte, M. (2015). Spotlight on Canadians: Results from the General Social Survey. Volunteering and charitable giving in Canada. http://www.statcan.gc.ca/pub/89-652x/89-652-x2015001-eng.pdf.

17. Samuel, D., Vilardo, N. Isani, S. (2019). Readability assessment of online gynecologic oncology patient education materials from major governmental, non-profit and pharmaceutical organizations. Gynecologic oncology, 154(3), 616-621.

18. Leber, A. I., Borocki, J., Radisic, J., Slusarczyk, B. (2017). Fostering Alliances with Customers for the Sustainable Product Creation. Sustainability, 10(9), 3204. 